\title{
Listening and the Well-tempered Controversy (With Reference to Intercultural Exchange)
}

\author{
Rodica Amel \\ Bucharest University
}

\begin{abstract}
The issue of this study continues the analysis of persuasive truth (the "truth" of beliefs), a problem debated by us in several articles already published, especially in two of them: Doxastic Dialectics (1999) and The Probable and the Problem (2010). In this new "chapter," our intention is to develop more details from the perspective of subjectivity, which has a grounding role in doxastic dialectics. Doxa's axiomatic mechanism tries to temper the subjective dimension of persuasive truth, by submitting the doxastic proofs to the control of the oppositional principle (=antithetic "reasoning"). Doxastic thinking discovers dialectically its own ratio (=measure), progressively increasing the relevance of the listening capacity. In the text that follows, the concept of listening is used in a larger than sensitive sense, being equivalent to condition of receptivity.
\end{abstract}

Keywords: persuasive truth, (ontological) hermeneutics, horizon, doxastic dialectics, subjectivity, original proof, conditions of receptivity

\section{Preliminary Assignments}

(1) Generally speaking, the dialectical study of persuasive truth is a kind of semantic logic.

(2) The semantic logic compatible with the doxastic field is based on subjectivity, in relation to which cognition means understanding (the meaning), not knowing (the truth).

(3) From the philosophical point of view, subjective cognition is led by the same three principles as the analytical cognition is: the principle of identity, of opposition, and of relevance.

(4) Within the doxastic field, the principle of opposition (having in mind an intercultural dialogue/respectively, a controversy) governs the efficiency of the other two principles ("searching for identity," and, respectively, "searching for relevance"). To put it simply, our remarks will stress the importance of antithetic reasoning in challenging the subjects' cognitive intentionality.

(5) Understanding the meaning of a doxastic expression is more than linguistic perception, more than explaining the speaker's meaning. It presupposes a creative ability to establish associative links, which weave the tissue of a moral (=intelligible inner) experience. Consequently, we have tried to extend the pragmatic concept of meaning, by adding a phenomenological dimension.

\section{Philosophical Target and Theoretical Means}

From the pragmatical point of view, the position of listening is reversible, derived from the oppositional

Rodica Amel, Dr., retired, Department of Foreign Languages, Bucharest University, Romania; main research fields: Modern Linguistics-Pragmatics, Semiotics, Philosophy of Language. 
principle. While listening, the attitude of each partner is critical: other- and self-oriented. From the phenomenological point of view, listening is a function of consciousness, derived from the same oppositional principle. The consciousness of a listening partner increases the cognitive functions of both partners: in the first stage, by tempering the subjects' expressive will, and in the second stage, by increasing the subjects' need to increase the meaning relevance of the controversial issue.

The cognitive intentionality of subjectivity is turned towards itself, trying to objectify the immanent condition (the condition of self) by self-reflective proofs. Therefore, a well-tempered doxastic dialectics means a well-tempered subjectivity. During doxastic dialectics, the subjects activate the expressive function of language while referring to a certain thing/fact. Well-tempered dialectics is an issue that regards both the speaker and the listener, by balancing the expressive will with the will of understanding. Due to the control of the oppositional principle, doxastic dialectics could be considered the "mechanism" of the "rational" interpretation of meaning. Having in view the Principle of Probability by which belief is generally defined, the theoretical investigation is to proceed systematically in another direction than that of epistemic research of controversy. Instead of speaking about the truth of beliefs, we shall search their meaning and develop the process of their understanding, in the hermeneutical sense.

In order to reach this target, we shall make a step backwards elucidating the question: How can subjectivity, a variable parameter, be tempered during doxastic dialectics.

The philosophical way we follow goes beyond pragmatics, meeting hermeneutics, that of Heidegger. We have in mind Heidegger's interpretation of "understanding as a mode of being," and nevertheless those of H. G. Gadamer and P. Ricoeur. ${ }^{1}$

"Well-tempered controversy" - approached, in this study, with reference to intercultural exchange — does not mean bridging oppositions between different points of view, but cognitive movements that subjectivity should accomplish in order to reach objectification of beliefs. Neither is our intention to offer a normative model, but to emphasize the axiological way of getting the original proof of relevance. The simplest answer to reach such a target would be to eliminate the fallacious way of "hot rhetoric," namely to eliminate all arguments subjectively distorted. The much stronger answer we intend to offer, is to reach a deeper level of dialectics and to demonstrate how subjectivity opens itself to dialogue. The subject, which is a closed universe, should learn to "listen." The concept of listening is used in a larger than its sensitive sense, being equivalent to condition of receptivity.

Subjectivity gets dialectically its own sense, maintaining under control the condition of receptivity. ${ }^{2}$

\section{The Principle of Opposition}

\subsection{The Grounding Role of an Alternative Subjectivity}

Controversy is an intersubjective confrontation. The subject's cognitive dynamic joins his pragmatic intentionality with the phenomenological intentionality. During controversy both subjects are intentionally oriented towards their cognitive target, each of them "affected" by the effort of increasing their creative power of understanding: understanding each-other and understanding the issue they are speaking about.

The objectifying intentionality of the subject is not a positive "measure," but a dynamic approach, an intention, a way towards what the subject wants to say, towards himself. The subject's effort is to make a bridge between opinion (=language) and belief (=a content posited in consciousness). The introspective power of the Ego (=the subject) is (originally) intentioned to find in his immanent condition the "stem" of subjectivity, 
namely the sense of Ego's existential condition, and to name it. In other words, the essential problem debated here regards the origin of language, ${ }^{3}$ language being the original measure of the subject's own expression.

While each locutor utters his opinion, he challenges both his partner's cognitive intentionality and his own in the same proportion. While interpreting his partner's words, the participant in a dialogue, as a subject, is intentionally oriented towards his own self, being on the way of assuming in his consciousness a sense, the sense of his beliefs, the sense of himself. Once an exegetic opinion is confronted with another opinion, both interlocutors evaluate reciprocally the content of their own beliefs, and in this way, they can measure the meaning extension of the expressed words: the field of debate. By increasing the introspective power of subjectivity, the confrontation between different opinions becomes the original way towards understanding.

An intercultural controversy begins to be well-tempered only when both participants are ready to listen to each other. They should be convinced that the cognitive target could not be reached without a good control on the conditions of reciprocity, and respectively of receptivity. By neglecting this condition, controversy would be unable to stimulate the original power of the subjects to assume the sense they are looking for in their consciousness.

To be a good listener means to observe pragmatic and hermeneutic conditions: both to understand correctly the partner's/speaker's meaning and to detect discursive incongruities. A metadialogue by means of which interlocutors put in order their conditions of reciprocity is engendered. In order to fulfill the condition of receptivity, each partner should manage a phenomenological reduction of his own beliefs, and should impose the same condition on the respondent. Socrates' maieutic inquiry is the best example of a tentative to establish a "well-tempered" dialogue. In a dialogue, if one of the participants gets an improper relevance ${ }^{4}$ of his own or of his partner's speaker's meaning, he has no adherence to the issue. If he ignores the other's belief(s), or he is unable to understand it correctly, then we may actually say the respective partner has no capacity of listening: Consequently, no further controversy is possible.

As we have already said, understanding the meaning of a doxastic expression is more than linguistic perception. The creative ability to establish associative links introduces higher meaning levels which contain moral explanations.

On another occasion (Amel 2014), we have tried to extend the pragmatic concept of the speaker's meaning, by adding a phenomenological dimension:

The speaker's meaning is a cognitive parameter, pragmatically defined. If this parameter acquires a moral dimension, the cognitive load is increased, requiring axiological determination. From this point on, the interpretative exigency steps beyond the pragmatical border and begins a hermeneutical inquiry. (Amel 2014, 109)

The phenomenological extension of the concept of the speaker's meaning is for the interpreter (=interlocutor) a guide, helping him to go beyond what the speaker said and to detect the speaker's moral attitude.

When contradictory opinions are confronted, the listening capacity is increased, because the cognitive intentionality of each participant is alerted: they are cognitively more vigilant. The subjective ground of beliefs is spontaneously inquired.

\subsection{Intercultural Field and Hermeneutics}

Any kind of controversy observes the dialogue's rules of rationalization, having the same basic structure.

Intercultural relationships represent interactive - frequently semiotical-contacts, but not in a usual communicative way, that of offer and reply. In an extended sense, we may say that the cultural phenomenon is a 
"language" of signs and symbols, of rituals. When cultures are in contact, each subject or performer-each being representative of a different semiotic system - is trying to decipher the partner's codes. "Making cultures reciprocally intelligible, despite their differences" means "Give them the chance to communicate." In a time of economic and political globalization, to communicate means to share standard values. Congress organizers try to remind everybody the grounding condition of cultural confrontations: the consciousness of the other, of a partner, of a reality different in shape. The respective remark is not phenomenologically approached. Devoid of substance, this idea has become a cliché, because the progress, like a big road roller, flattens down historical and national values.

We refute any analogy between cultures in contact and forms of communication, firstly, because we invoke a formal consideration: the strict dialogical pattern, that of offer and reply. Within this pattern, the communicative function of language is basically referential (we say something about something), while the communicative function of rituals, of cultural signs and symbols, is basically expressive. Regarding the possible affirmation that: "Cultures in contact are more likely as languages in contact..." we want to bring the following remark. Actually, cultures in contact are not exactly like languages in contact. Learning "the other's language" could never saturate intercultural relationships. Behavioral practices exhibit cognitive patterns and emotional habits; by them, the performers express their moral identity. Cultural practices have an inner dimension; they stimulate the reflection, questioning the sense of human condition and that of human spirit, transferred in patterns of life.

The implicit target of a listener, involved in a cultural debate, is firstly to uncover his own identity by discovering the other's identity, in the symbolic forms each of them shares. Intercultural reciprocity means more than a simple relationship; it is an exposure of the existential Erfahrung, acquired through hermeneutical steps and structured in opposite terms. Hermeneutical procedure is very different from pragmatic interpretation. $^{5}$

Secondly, when the sense of communication is too large, it has no formal application. "Making cultures reciprocally intelligible, despite their differences" is an irrelevant desideratum. Usually, intercultural relationships are reduced to a society game of festivals and competitions, the first reaction being: "With them, like with us," or something like making jazz from Bach music, or discovering Irish motives in Vivaldi's concertos.

If we choose communicative means within an intercultural contact, what we discover is that the respective means are not strategically oriented, but disposed in a contrastive way. The emphasis should be put on the contrasting voices, each voice announcing a profession of faith. The expressive dimension encompasses axiological and moral arguments. All together compose a semantic field, in which the essence of human life is hidden. Before partners in an intercultural confrontation can explicitly emphasize the relevance of their axiological and moral arguments (=opinions), a reciprocal discovery displayed throughout the line forces of belief is needed. Partners objectify the dialogical distance existing between them, intending to discover a possible unifying horizon.

What we call here (cultural/axiological etc.) "horizon" is a paradigmatic and not a pragmatic determination of meanings. The horizon is explicitly or implicitly established or recognized as being a "general proposition," a system of reference-concepts, symbols, rituals etc.-for a certain/particular doxastic expression. We should accept this definition as a formal one. 
In the extent to which the systems of reference are dialogically validated by hermeneutical acts, the cognitive interest can be delimitated within a horizon. The dialectical constitution of the cognitive interest allows us to refer to the concept of interactional field. Some specifications should be mentioned: (a) within a (dialogical) game, the field is apriorily delimited; (b) within a verbal non-regulated interaction (including epistemic controversy), the field is operationally delimited. The opponents try to establish a metalanguage (a system of reference) in order to control the dialogical terms. We should not forget that the intercultural confrontation is a verbal self-oriented interaction, and because of this reason it is more difficult to find a common metalanguage.

The theoretical concept of field was introduced as a tempering means. Each participant can assume his personal identity - namely, can temper his subjectivity (a variable parameter) in virtue of the principle of opposition, active in the presence of an alternative (partner's) identity.

Within a regular dialogue (even epistemic), the opponents/the "players" start their interventions following strategic plans of "gaining the game." The selective attitude in taking turns begins with an identification inquiry: Who is the interlocutor? This is the question raised in any form of reciprocity. Consciously or not, explicitly or not, an intercultural "player," while raising the respective question sets out on the hermeneutically long way into the deep night of signification. By watching one's own and the other's habits and reactions, the "cultural player" is asking this question for himself. The contrastive way in which each one uncovers his own identity, within a semantic field, engenders creative forces: both interpretative/exegetic and expressive/artistic. What in French is called prise de conscience, a self-reflection, becomes well-tempered in a contrastive way. Une prise de conscience, reached in contrastive conditions, clears the life of symbols within society.

\section{4. “To Acquire a Horizon of Interpretation Requires a Fusion of Horizons" (Gadamer 2004 PDF, 398)}

In a cultural controversy, the role of a good listener (an alternative subject) is to urge the expressive function of language (=by belief objectification) and, then, to urge the process of doxastic rationalization (="la conquête de l'horizon"). Gadamer's remark regarding "la conquête de l'horizon" can be referred to two hermeneutical steps: (a) to follow the proper way by means of which beliefs at issue could be tempered; (b) to establish the paradigmatical terms of the controversial issue. In each of these steps, the consciousness of the other has the role of a meaning catalyst. Aiming at the "fusion of horizons," the partners (both subjects) are "pushed" to continue the meaning interpretation, a target rarely reached.

\subsection{The Existential Meaning (Personal Belief) Is Not Yet a Measure}

Doxastic dialectics engenders a heuristic interest (=cognitive intentionality) stronger than reaching a name for the meaning posited by each participant in his consciousness. The personal belief is troubled once confronted with an alternative belief. Interlocutors accept cultural pluralism. Each partner while listening to the other's voice is listening to his own. In spite of the lucid consideration that the variable parameter allows cognitively provisional results, partners in a cultural controversy are ready to extend the field of meaning inquiry.

Doxastic dialectics is language dependent, not only during the process of its development, but also in its heuristic finality. Doxastic concepts are introspectively never saturated. Their interpretation is continuously reshaped. The cognitive interest is oriented towards progressively higher levels of axiological determination, opening ever-new axiological horizons. 
Meaning becomes relevant if perceived from an ever higher/paradigmatic level. The meaning-oriented procedure requires proofs of evidence: a meaning horizon.

\subsection{Common Ideas}

In our interpretation, a hermeneutical process is well tempered if the subjects get (understand) the relevance of those values defining their own existential condition. At this moment, the relevance of existential meanings is proved in confrontation with common ideas chosen by society at a given historical moment: axiological paradigms - systems of reference - semiotic patterns (styles, symbols, rituals etc.). Having in view the critical position of subjectivity, reference systems are submitted to the same control of reciprocity. They are actually (re)constituted, and not given (Amel 2008). The meaning interpretation is in an increased process of conceptual synthesis. ${ }^{6}$ Doxastic dialectics develops ever-new semantic/semiotic horizons within which the personal Erfahrung (the belief represents the intelligible experience) becomes more and more persuasive/pertinent. Value pertinence is a relative measure, but humanity recognizes it if the respective measure opens a higher horizon of understanding, if the distance from nature to culture, from a subjective position to a higher level of relevance could be transgressed. For instance, Nietzsche's memorable interpretation of man's contingent qualities, which, projected on archetypal structures, get existential relevance.

How well the Greek nature is able to use all its dreadful qualities: The Asian orgiastic impulse results in Dionysism, the individual's hostile reserve results in Apollinism! (see Fr. Nietzsche 1969).

Another interesting example is Al. Baumgarten's philosophical book (2008) in which the belief in "our daily blue heaven" is raised to the level of a philosophical concept: the principle of heaven. ${ }^{7}$

\section{Conclusion}

The hermeneutical process, during which subjectivity has the grounding role, never starts from zero.

(1) In the hermeneutical context, each ontological interpretation requires a perceptive evidence: a basic "idea" which the subject takes for granted, a premise. Ironically, the starting point of existential interpretation cannot be a genuine experience. It is, say the philosophers, prejudiced by tradition or by time spirit (Zeitgeist) with its culturally dominant spirit, or even more dangerous, prejudiced by ideologies, dogmas, loaded words, or cultural clichés. The critical attitude of the self (both the self of the $I$ and that of the other) detects the void sound of irrelevant proofs.

Therefore, conditions of receptivity are troubled. What is Given (the premise) should be inquired. The retroactive movement of doxastic "logic," called hermeneutical circle, inevitably starts with a premise the relevance of which becomes the object of controversy. Doxastic premises are continuously questioned. Nevertheless, this step of hermeneutical interpretation cannot be avoided, because thinking needs a base of receptivity, which represents the very possibility condition of thinking: "Prejudices are simply conditions whereby we experience something" says H. G. Gadamer $(1977,9)$. We totally agree with Gadamer's further remarks:

Prejudices are not necessarily unjustified and erroneous, so that they inevitably distort the truth. In fact, the historicity of our existence entails that prejudices, in the literal sense of the word, constitute the initial directedness of our whole ability to experience. Prejudices are biases of our openness to the world. (Gadamer 1977, 9)

(2) The premises of axiological judgment are searched within a "language horizon" already given and simultaneously inquired. This is a case where petitio principii is not a fallacious way of thinking. 
Important for our present argument is that listening represents an existential involvement. Listening represents the very condition for assuming a sense in consciousness. An existential meaning is more than a meaning; it is a value, namely, a sense granted with moral objectivity - a spiritual power. Confronted with several systems of reference (given or re-constituted) - moral concepts, symbols, rituals, etc.-values are invested with spiritual power, able, in their turn, to ground patterns of life. In this new step, values prove their "true" (actual) objective relevance.

"Objectivity" regarding values is a virtual feature, a phenomenological way of defining the moral IDEAs as cognitive OBJECTs. Although we affirm the objective "substance" of values, this "objectivity" does not mean uncontested autonomy. We share the idea/opinion that values have historical relevance. A good listener says: men never get the final sense of life condition.

\section{Notes}

1. See P. Ricoeur's explanation (2004, 10-11): "The understanding which is the result of the Analytic of Dasein is precisely the understanding through which and in which this being understands itself as being."

2. Although we share P. Ricoeur's critical point regarding Heideggerian hermeneutics that Heidegger "gives us no way to show in what sense historical understanding, properly speaking, is derived from this primordial (/ontological) understanding $(2004,10)$," we do not develop P. Ricoeur's criticism. What we mean by well-tempered doxastic controversy and our whole explanation is only indirectly an answer to the question raised by Ricoeur: "How can the conflict of rival interpretations be arbitrated? $(2004,10) . "$

3. "Language is the house of Being/Die Sprache ist das Haus des Sein" (Heidegger, Humanismus, 1957, 24; 1959, 166; 1976, 313). Cf. also Heidegger: "Im Denken das Sein zur Sprache kommt. Die Sprache ist das Haus des Seins. In ihrer Behausung wohnt der Mensch (1976, 313)."

4. It is important to make the difference between pragmatic relevance and hermeneutical relevance. The concept of relevance represents a benefit of meaning. Pragmatic relevance is obtained when a dialogical intervention is referentially connected to another. Hermeneutical relevance is obtained when the meaning interpretation of an opinion/belief gets conceptual determination. The hermeneutical relevance represents a meaning operation, namely a meaning synthesis (see note 7 , here after), by projecting the subjective meaning on a moral horizon or idea.

5. From the pragmatic point of view, the object of "interpretative" acts is to discover why the partner has said what he has, namely, to discover the utterance's and speaker's meanings, by making bridges between posed in presupposed facts. For instance: ELLE: Crétin. Séducteur! LUI: Ne m'insulte pas. Ne m'appelle plus séducteur. Tu n'as pas honte? ELLE: Je ne t'insulte pas. Je te démasque (E. Ionesco, Délire à deux, 206). The little fragment quoted above is an example of an interpretative conflict regarding the "speaker's meaning:" The speaker's intention was not to insult, but to unmask, to show up the truth.

6. Conceptual synthesis is a semantic operation. In our hermeneutical approach, conceptual synthesis represents the meaning coagulation on the paradigmatic level. While the subjective reasons of believing are dialectically inquired, they are objectified in a conceptual form. All the operations are semantic and not analytical, and they progressively lead to higher levels of understanding.

7. Al. Baumgerten (2008) based on rigorous exegeses of medieval philosophers and theologians, tries to answer updated questions: Can we speak about the universal unity of thinking? Whether the medieval dispute regarding the principle of heaven, as "image" of thinking universality, could get actual relevance? Still from antiquity until recently — says the Romanian philosopher, there are voices, which affirm that although thinking assumes a universal principle (heaven, ideal city, intellect/nous), this very principle cannot settle all cognitive interrogations. There remains a rest impossible to be reached by human mind and which represents the "condition of possibility" of the thinking itself.

\section{Works Cited}

Amel, R. "Doxastic dialectic." RRL. XLIV (1-4) (1999): 3-12.

---. "Dreapta potrivire a numelor (The Correctness of Names, Plato, Cratylos)." Proceedings of the 6th Colloquium of the Department of Romanian Philology. Bucharest: EUB, 2007. 223-62.

---. "Sign Systems-Reference Systems." Kodikas 31.1-2 (2008): 59-68.

---. "The Probable and the Problem." Proceedings of the Seventh International Conference ISSA. Eds. F. H. van Eemeren and Alias. Amsterdam: Sic Sat, 2011. 
---. "Speaker's Meaning. With Reference to M. Dascal's Book Mashav Ha-Ruah.” Perspecives on Theory of Controversies and the Ethics of Communication. Explorations on Marcelo Dascal's Contributions to Philosophy. Eds. D. Riesenfeld and G. Scarafile. Heidelberg: Springer, 2014. 101-12.

Baumgarten, Al. Principiul cerului. Humanitas: Bucureşti, 2008.

Dascal, M. "The Controversy about Ideas and Ideas about Controversy." Controversias Cientificas e Filosoficas. Ed. F. Gil. Lisboa: Fragmentos, 1990.

---. "Epistemologia, controversias y pragmatica." Isegoria 12 (1995): 8/43.

---. "Some Questions about Misunderstanding." Journal of Pragmatics 31 (1999): 753-62.

---. "Leibniz and Epistemological Diversity." Unita e moltiplicita nel pensiero filosofico e scientifico di Leibniz. Simpozio Internazionale. Roma: Olschki Editore, 2000.

Dascal, M. and S. Cremaschi. "The Malthus-Ricardo Correspondence: Sequential Structure, Argumentative Patterns and Rationality.” Journal of Pragmatics 31 (1999): 1129-72.

Gadamer, H.-G. Truth and Method (second revised edition, trans. Joel Weinsheimer \& Donald G. Marshall). London, New York: Continuum, 1989 (the quoted edition PDF 2004).

---. "The Universality of the Hermeneutical Problem.” Philosophical Hermeneutics. Trans. and ed. Linge, E. David. Berkeley, Los Angeles, London: University of California Press, 1976b. 3-17.

---. "Vom Zirkel des Verstehens.” Kleine Schriften, IV. Tübingen: J.C.B. Mohr, 1977.

---. Was ist Wahrheit? Hermenetik II, Gesammelte Werke. Tübingen: J.C.B. Mohr, 1986.

Grice, P. The Conception of Value (introd. Judith Baker). Oxford: Clarendon Press, 1991.

Heidegger, M. Der Satz vom Grund. Tübingen: Neske Verlag, 1957.

---. Unterwegs zur Sprache. Tübingen: Neske Verlag, 1959.

---. Briefe über den Humanismus: Lettre sur l'humanaisme (texte bilingue). Paris: Aubier, 1964.

---. Brief über den Humanismus. Gesamtausgabe, Band 9. Frakfurt/M: Vittorio Klostermann, 1976. 313-69.

---. Der Satz vom Grund. Gesamtausgabe, Band 10. Frankfurt/M: Vittorio Klostermann, 1977.

---. Einführung in die Phänomenologische Forschung. Gesamtausgabe, Vol. 17. Frankfurt am Main: Vittorio Klosterman, 1994.

---. Problemele fundamentale ale fenomenologiei. Trans. B. Mincă and S. Lavric. București: Humanitas, 2006.

Nietzsche, Fr. La naissance de la philosophie à l'époque de la tragédie grecque. Paris: Gallimard, 1969.

Plato. The Collected Dialogues. Eds. E. Hamilton and C. Huntington. New York/New Jersey: Princenton University Press, 1969.

--- Protagoras. Trans. Serban Mironescu. Vol. Opere, Vol. I. Eds. P. Cretia and C. Noica. Bucuresti: Ed. Stiintifica si Enciclopedica, 1975.

Ricoeur, P. (2004 reprinted). "Existence and Hermeneutics." Conflict of Interpretations. Trans. Kathleen McLaughlin. Northwestern University Press, 1974. 3-23.

Vattimo, G. Beyond Interpretation. Trans. David Webb. Cambridge: Polity Press, 1997. 